\title{
The wolf Canis lupus as natural predator of beavers Castor fiber and Castor canadensis
}

\author{
Karl-Andreas Nitsche
}

\begin{abstract}
An overview of wolves as natural predator of the beaver in Eurasia and North America will be given. The impact of wolf on beaver populations is depending on local and seasonal conditions. Wolves are not able to reduce beaver populations. Our knowledge about the relations between beaver and wolf is still incomplete and should be further examined.
\end{abstract}

KEY WORDS: beaver, Castor fiber, Castor canadensis, wolf, Canis lupus, predation.

Karl-Andreas Nitsche [bibernitsche@gmail.com], Akensche Str. 10, D-06844 Dessau-Rosslau, Germany.

\section{Волк Canis lupus как естественный хищник для бобров Castor fiber и Castor canadensis}

\begin{abstract}
К.-А. Нитше
РЕЗЮМЕ. Дан обзор хищничества волка по отношению к бобру в природных условиях Евразии и Северной Америки. Влияние хищника зависит от локальных и сезонных условий. В целом, волк не в состоянии редуцировать популяцию бобра. Наши знания о взаимоотношениях волка и бобра недостаточны и должны пополняться дальнейшими исследованиями.
\end{abstract}

КЛЮЧЕВЫЕ СЛОВА: бобр, Castor fiber, Castor canadensis, волк, Canis lupus, хищничество.

\section{Introduction}

The wolf is spreading in Germany (Fig. 1). It thus settles areas inhabited by beavers (Fig. 2). Beavers are part of the wolf's natural prey composition. While there have been long-term researches on the percentage of beavers in wolf prey in North America and Eastern Europe, there will be a future development for this area with beavers occupying a corresponding part.

At the moment hoofed game animals is domineering the nutrition of the wolf, but an imprinting on certain prey, due to regional causes could lead to beavers becoming more important. The beavers, too, will adjust their behaviour and activity to the new predator. Relevant research has shown that the wolf is not in a position to regulate a widespread beaver population. In restricted areas, however, the influence of the wolf might not only antagonize beavers, but might also decimate the reproduction of the beaver. Of the numerous publications, some important researches are being summarized. It is suggested to examine beaver carcasses for a possible killing by wolves.

\section{Results}

Patch (1934) mentions the wolf as the most important enemy of the beaver in North America. Murie (1944) found but 2 proofs of beaver in 1174 wolf excrements in the years between 1939 and 1941 in the
Mount McKinley National Park, even though the beaver is widespread in the area. Only in case of a high stock was the wolf able to hinder the growth of the beaver population (Djoshkin \& Safonow, 1972). Bibikov (1990): "This is different with the beaver whose remains are found much more often in some areas and in certain seasons. The hunt for the beaver is most successful when the rodent leaves the water". Baker \& Hill (2003): "Predation by the timber wolf (Canis lupus) can be an important limiting factor of beaver populations where they occur together."

According to Pavlov (1990) some solitary wolves or wolf packs specialize on certain prey, one of which might be the beaver. Wolves in central Ontario had a maximum of $75 \%$ beaver in their diet (Voigt et al., 1976, quoted in Jenkins \& Busher, 1979). Mech (1994) lists the beaver as the most important secondary nutrition next to hoofed game animals (Table 1).

The 121 proofs are listed by author for 5 areas in North America. Beavers are caught by wolves mainly at ice holes in winter. When looking for food, wolves regularly check beaver settlements and beaver lodgings. On lakefronts and river banks they get their bearings by marking piles of the beaver which are provided with fresh castoreum. They follow the crossings and then capture the beavers on land or when they leave the water. Bush (1996) writes that beavers are an important alternative nourishment for wolves in central and northern Canada in summer, especially when wolves hunt alone. In Denali, beavers are important as nourishment 
Distribution of wolf (Canis lupus) in Germany / monitoring 2014

(1.5.2014 - 30.4.2015)

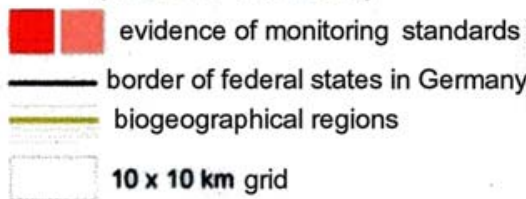

\section{Geobasisdaten: $\odot$ GeoBasis-DE / BKG 2011}

Source: Bundesamt für Naturschutz (BfN) update: 26. 11. 2015

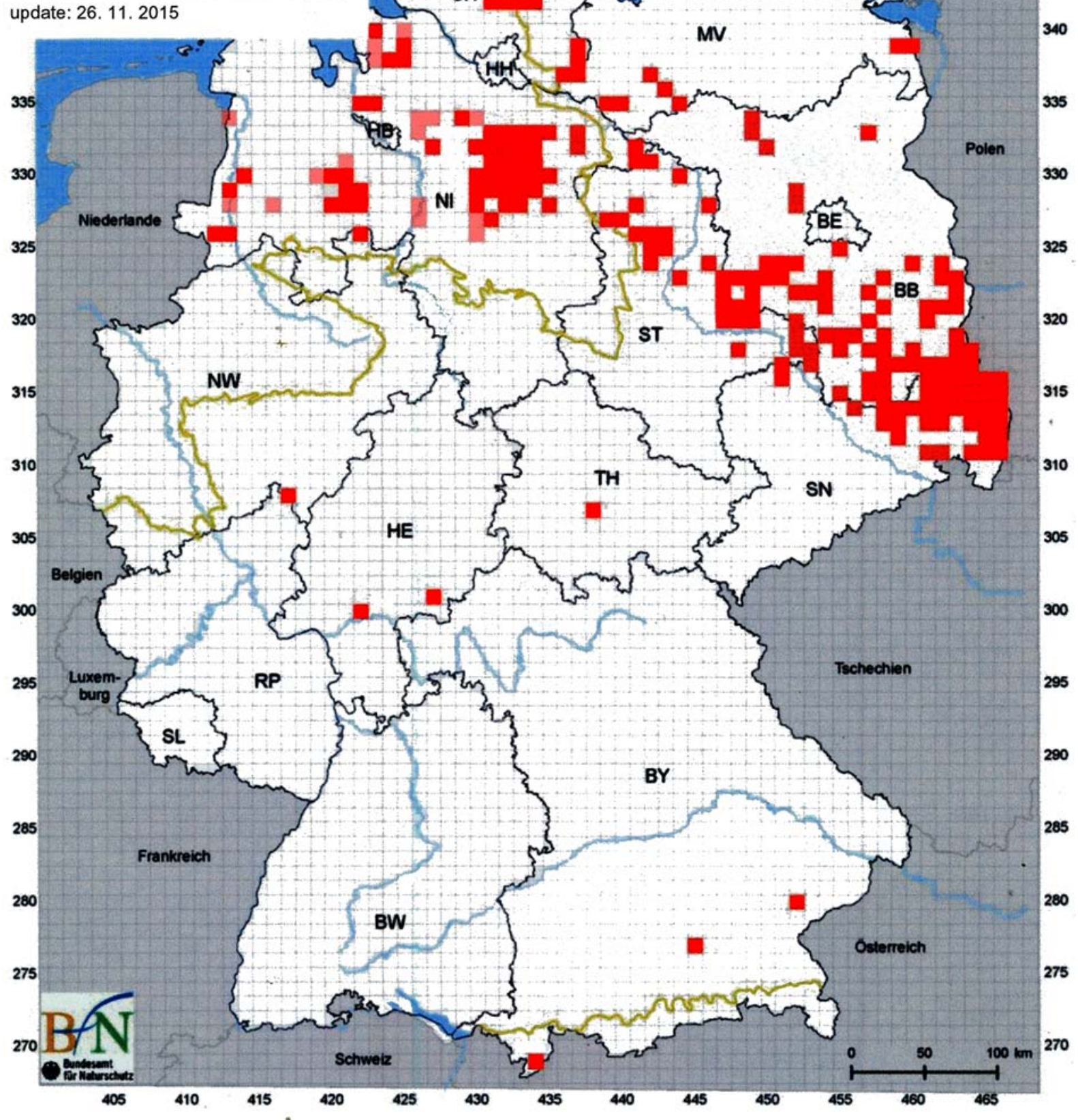

Fig. 1. Distribution of wolf (Canis lupus) in Germany, 2015. Source: Bundesamt für Naturschutz, BfN. 


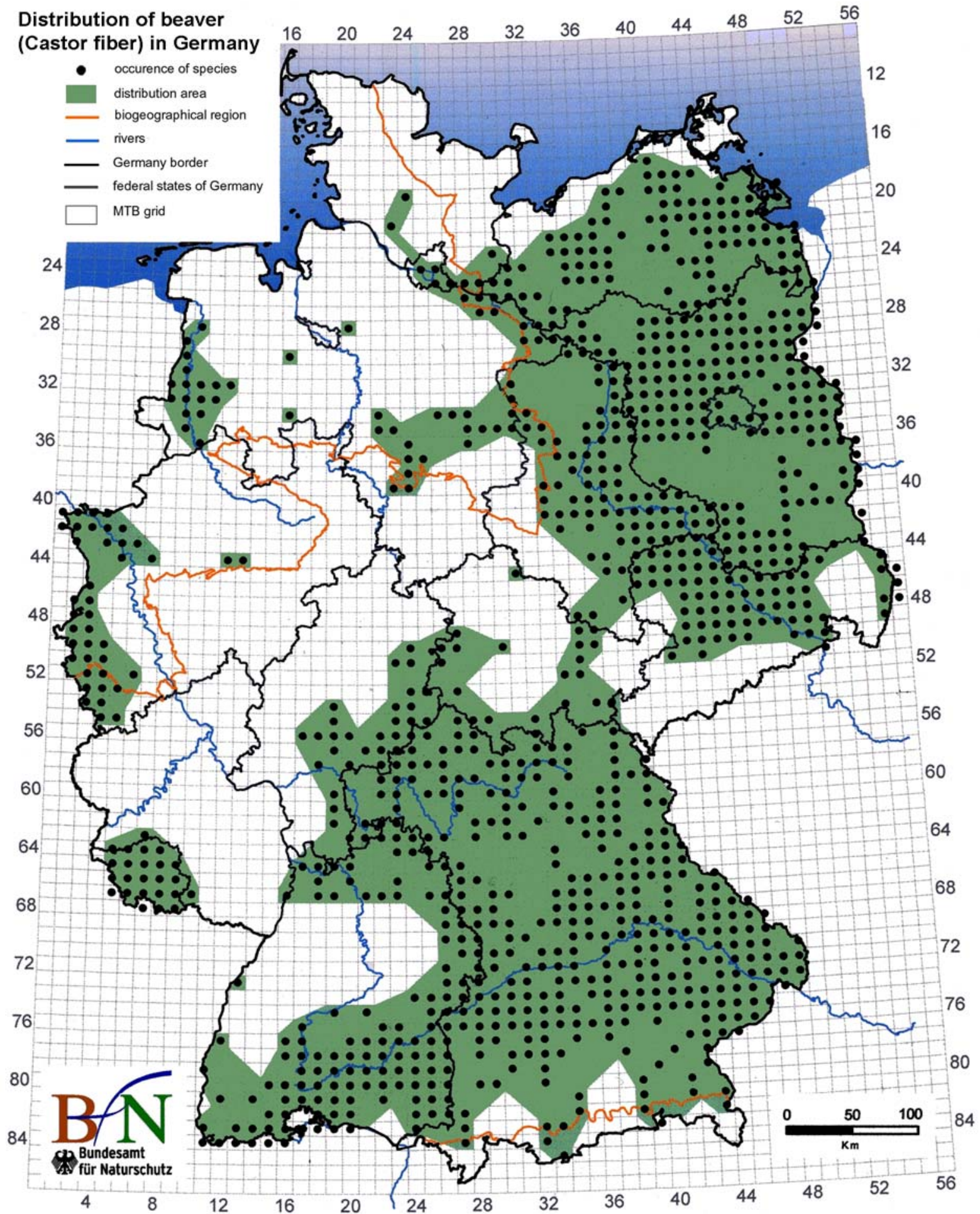

Fig. 2. Distribution of beaver (Castor fiber) in Germany, 2013. Source: Bundesamt für Naturschutz, BfN).

in late winter, when other food is hard to find. Andersone (1999) examined the prey spectrum of wolves in Kemeri National Park in Latvia and diagnosed that beavers represent $30.3 \%$ of the summer diet of the wolf, which constitutes a proportion of $36.1 \%$ of the entire amount of food (Figs 3-4). After the collapse of the fur market in Latvia, wolves have been the only factor to limit the growth of the beaver populations (Andersone, 1999). Regarding the wildlife management area in the district South-Favo in Finland, Harkonen (1999) names 
Table 1. Beaver remains in wolf excrements.

\begin{tabular}{|l|c|l|}
\hline \multicolumn{1}{|c|}{ Area } & $\begin{array}{c}\text { Percentage (\%) of wolf } \\
\text { excrements with beaver remains }\end{array}$ & \multicolumn{1}{c|}{ Source } \\
\hline $\begin{array}{l}\text { Rocky Mountain National Park, } \\
\text { Canada }\end{array}$ & 7.0 & Cowan, 1947 \\
\hline Ontario, Canada & 10.5 & Peterson, 1955 \\
\hline $\begin{array}{l}\text { Algonquin Provincial Park, } \\
\text { Ontario, Canada }\end{array}$ & $\begin{array}{c}62.8 \text { (in summer) } \\
11.5 \text { (in winter) }\end{array}$ & $\begin{array}{l}\text { Theberge } \text { et al., } \\
1978\end{array}$ \\
\hline Isle Royale in Lake Superior, USA & 11.0 & Mech, 1966 \\
\hline Minnesota, USA & $\begin{array}{c}10.0-47.0 \text { (in April/May) } \\
2.0 \text { (in June/July) }\end{array}$ & Fuller, 1989 \\
\hline Latvia & 30.3 (in summer) & Andersone, 1998 \\
\hline Voronezh Nature Reserve, Russia & $\begin{array}{c}5.3 \text { (in summer) } \\
15.3 \text { (in winter) }\end{array}$ & Mertz, 1953 \\
\hline
\end{tabular}

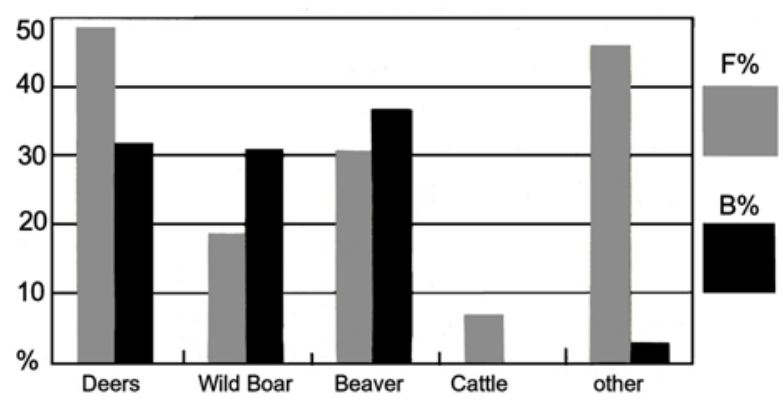

Fig. 3. Summer diet of wolf in Latvia $(n=33), \mathrm{F} \%$ - frequency of distribution, $\mathrm{B} \%$ - percentage of consumed biomass (after Andersone, 1999).

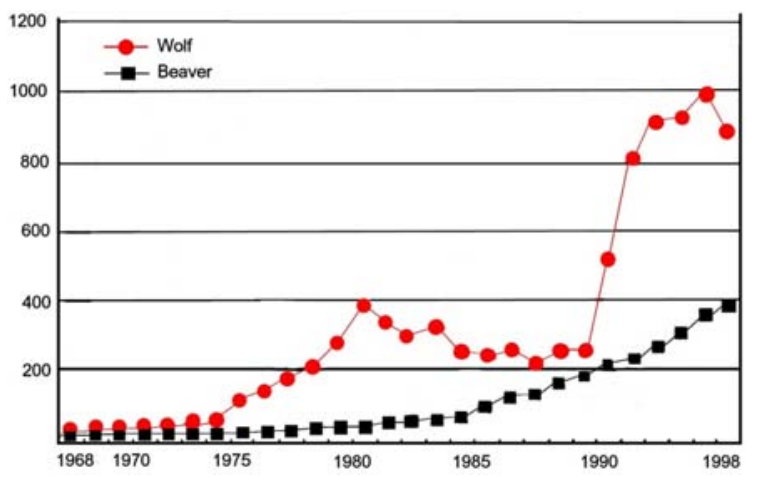

Fig. 4. Population development of beaver and wolf in Latvia from 1968 to 1998; numbers in beavers $\times 100$ (after Andersone, 1999).

the wolf as predator, especially in spring. Bloch \& Bloch (2002) describe a young wolf's attempt at catching a beaver. They mention that according to season and habitat, beavers make up to $35 \%$ of the daily food intake of a wolf and that some wolves have specialized on hunting beaver. Zavyalov (pers. message on 30/12/ 2010) wrote to me that in the Rdeisky Zapovednik (Novgorod Province) 5 times more beaver snatches had been found at ponds with low water levels in October and November 2010. Potvin et al. (1992) examined whether wolves were able to regulate a beaver population. The result was negative. Muller-Schwarze \& Sun (2003) are the only authors to list the red wolf (Canis rufus) as a beaver hunter.

The first examination of food residues of the wolf in Germany - area of examination Königsbrücker Heide (Saxony) - took place in the year of the first litter. In 2011 beaver remains in wolf nourish-ment have been found in 3 beaver territories between April and July. During a spot survey between April 2011 and July 2012 12 beaver remains could be proved in excrement samples $(n=116)$. According to frequency and calculated biomass, the percentage of beaver amounts $10 \%$, a figure which is considerable for the local beaver population. The following authors list the beaver as wolf prey without naming details: Mills (1913), Warren (1928), Bradt (1947), Hinze (1950), Semyonov (1951), Heptner (1956), Parovshikov (1960), Canadian Wildlife Service (1973), Banfield (1974), Stubbe \& Dawaa (1983), Nowak (1987), Strong (1997), Forsyth (1999), Kitchener (2001), Danilov (2009).

\section{Discussion}

In his book "The beaver of the European part of the Soviet Union" Dyakov (1975) only summarizes the Russian literature. Danilov et al. (2007) describe beaver hunters in detail. In deep water there is no danger of predators for the beaver (except alligators in southern US states).

The chances for an effective beaver hunt increase when water bodies dry out or when water runs off after the destruction of dams. The majority of snatched beavers are inexperienced young animals in their first or second year. Some wolves have specialized on beaver as prey. They catch young beavers at their lodge when they are unprotected and there is no means of escape. During icing in winter, when beavers, in order to find food, have to open their lodge to the landside, they are as easy to be snatched as in spring, when they are more active in food intake or in autumn, while felling trees. The beaver, with a weight of up to $35 \mathrm{~kg}$ is a big and 
easy to catch prey for wolves. However, there are only few studies on the relationship between the carnivores in beaver territories and a possible food competition. Stubbe \& Dawaa (1983): Next to the Bulgan River (Mongolia) there is a high food competition between carnivorous mammals (wolf, red fox, badger, stone marten), as well as a high predation pressure on the beaver.

Kitchener (2001) gives a detailed description of the beavers defence mechanisms towards predators. It is not always possible to state precisely whether the food intake was from snatched beavers or from beavers who had died from other reasons (it can not be distinguished in excrement samples). When predators are present for a longer period of time, beavers learn to behave accordingly and react with an adapted activity pattern and increased defensive behaviour. The hunting strategies differ. Canids run along river banks or wait at ice holes. The beaver settlements in monotonous boreal coniferous forests are especially attractive to wolves since the bodies of water, dammed up by the beaver, and the marshland attract a great number of potential prey for food and water intake. Wolves are not able to limit or to decimate a beaver population. In future, beaver carcasses should be investigated for a possible predation by wolves.

ACKNOWLEDGEMENTS. Thanks to Dr. Zaneta Andersone (Riga) for information on behaviour of wolves in Kemeri National Park in Latvia. I would also like to thank Dr. Alexander Saveljev (Kirov) and Dr. Nikolay Zavyalov (Novgorod Province) for consignment of Russian literature and written messages.

\section{References}

Andersone Z. 1999. Beaver. A new prey of wolves in Latvia? Comparison of winter and summer diet of Canis lupus L. 1758 // Busher P.E. \& Dzieciolowski R.M. (eds.). Beaver Protection, Management, and Utilization in Europe and North America. New York, Boston, Dordrecht, London, Moscow: Kluwer Academic / Plenum Publishers. P.103-108

Baker B.W. \& Hill E.P. 2003. Beaver Castor canadensis // Feldhamer G.A., Thompson B.C. \& Chapman J.A. (eds.). Wild Mammals of North America: Biology, Management, and Conservation. Second edition. Baltimore: the Johns Hopkins University Press. P.288-310.

Banfield A.W.F. 1974. The Mammals of Canada. Toronto. $160 \mathrm{p}$.

Bibikow D.I. 1990. Der Wolf. Die Neue Brehm-Bücherei. Lutherstadt, Wittenberg: A. Ziemsen Verlag.

Bloch G. \& Bloch K. 2002. Timberwolf Yukon \& Co. Elf Jahre Verhaltensbeobachtungen an Wölfen in freier Wildbahn. Mürlenbach: Kynos Verlag. $261 \mathrm{~S}$.

Bradt G.W. 1947. Michigan Beaver Management. Lansing: Michigan Department of Conservation, Game Division. $56 \mathrm{p}$.

Bush R.H. 1996. The Wolf Almanac. New York: Lyons \& Burford Publishers. 226 p.
Canadian Wildlife Service. 1973. Beaver. Ottawa: Hinterland Who's Who Information.

Cowan I.M. 1947. The timber wolf in the Rocky Mountains national parks of Canada // Canadian Journal of Research. Vol.25. P.139-174.

Danilov P.I. 2009. Causes of death among beavers in the European North of Russia // Abstracts $5^{\text {th }}$ International Beaver Symposium. P.25.

Danilov P.I., Kanshiev V.Ya. \& Fyodorov F.V. 2007. [Beavers of the Russian European North]. Moscow: Nauka. 200 p. [in Russian].

Djoshkin W.W. \& Safonow W.G. 1972. Die Biber der alten und neuen Welt. Die Neue Brehm-Bücherei. Wittenberg, Lutherstadt: A. Ziemsen Verlag. 168 S.

Dyakov Y.V. 1975. [Beavers of European Part of the Soviet Union]. Moscow: Moskovsky Rabochiy. 480 p. [in Russian].

Forsyth A. 1999. Mammals of North America. Temperate and Arctic Regions. Willowdale: Firefly Books. 350 p.

Fuller T.K. 1989. Population dynamics of wolves in NorthCentral Minnesota // Wildlife Monographs. No.105. P.341.

Harkonen S. 1999. Management of the North American beaver (Castor canadensis) on the South-Savo game management district, Finland (1983-1997) // Busher P.E. \& Dzieciolowski R.M. (eds.). Beaver Protection, Management, and Utilization in Europe and North America. New York, Boston, Dordrecht, London, Moscow: Kluwer Academic/Plenum Publishers. P.7-14.

Heptner W.G. 1956. Die Säugetiere der Schutzwaldzone. Berlin. $167 \mathrm{~S}$.

Hinze G. 1950. Der Biber. Berlin: Akademie-Verlag. 247 S.

Jenkins S.H. \& Busher P.E. 1979. Castor canadensis // Mammalian Species. No.120. P.1-8.

Kitchener A. 2001. Beavers. Stowmarket: British Natural History Series White Books Ltd. 144 p.

Mech L.D. 1966. The Wolves of Isle Royale. Washington: U.S. Park Service, Fauna Series. No.7. 210 p.

Mech L.D. 1994. The Wolf. The Ecology and Behavior of an Endangered Species. Ninth edition. Minneapolis and London: University of Minnesota Press. 389 p.

Mertz P.A. 1953. Volk v Voronezhskoi oblasti. Ecologia hishnika, organizatsia bor'by [Wolf in Voronezh Province. Ecology of predator, organization of management] // Preobrazovanie Fauny Pozvonochnych Nashei Strany. Moscow: MOIP Publ. P.117-135 [in Russian].

Mills E.A. 1913. In Beaver World. Boston \& New York. $228 \mathrm{p}$.

Muller-Schwarze D. \& Sun L. 2003. The Beaver. Natural History of a Wetlands Engineer. Ithaca \& London: Cornell University Press. 190 p.

Murie A. 1944. The wolves of Mount McKinley // Fauna of the National Parks of the United States, Fauna Series. No.5. Reprint of 1971. P.55, 58-59.

Nowak M. 1987. Beaver// Wild Furbearer Management and Conservation in North America. Ontario: Ministy of Natural Resources. P.283-312.

Parovshikov V.Ya. 1960. Vragi bobra [Enemies of beaver] // [Proceedings of the Voronezh State Reserve]. Vol.9. P.99-100 [in Russian]. 
Pavlov M.P. 1990. Volk [Wolf]. Second edition. Moscow: Agropromizdat. 351 p. [in Russian].

Peterson W. 1955. Arizona's operation beaver lift // National Geografic Magazine. Vol.107. No.5. P.666-680.

Potvin F., Breton L., Pilon C. \& Macquart M. 1992. Impact of an experimental wolf reduction on beaver in Papineau-Labelle Reserve, Quebec // Canadian Journal of Zoology. Vol.70. No.1. P.180-183.

Semyonov B.T. 1951. Rechnoi bobr v Archangelskoi oblasti [Beaver in Arkhangelsk Province] // Trudy VNIOZ. Kirov. Vol.11. P.7-43 [in Russian].

Strong P. 1997. Where waters run. Beavers. Minocqua: North Word Press. 143 p.
Stubbe M. \& Dawaa N. 1983. Akklimatisation des Zentralasiatischen Bibers - Castor fiber birulai Serebrennikov, 1929 - in der Westmongolei // Exploration into Biological Resources of Mongolia. Halle (Saale). Vol.2. S.3-92.

Theberge J.B., Oosenburg S.M. \& Pimlott D.H. 1978. Site and seasonal variations in food of wolves in Algonquin Park, Ontario // Canadian Field-Naturalist. Vol.92. P.91-94.

Voigt D.R., Kolenosky G.B. \& Pimlott D.H. 1976. Changes in summer foods of wolves in Central Ontario // Journal of Wildlife Management. Vol.40. No.4. P.663-668.

Warren E.R. 1928. The most interesting wild animal in America // The Scientific Monthly, July 1928. Vol.27. P.39. 